\title{
当科における頭頸部再建の現況について
}

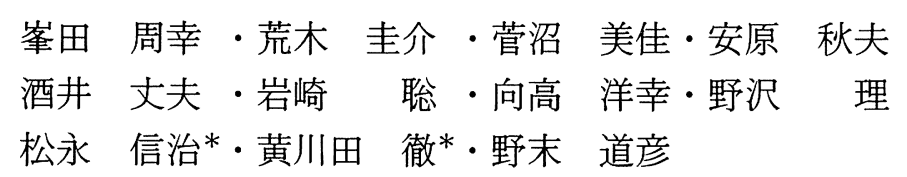

\section{Results of Reconstructive Surgery for Head and Neck Cancers}

\author{
Hiroyuki Mineta, Keisuke Araki, Mika Suganuma, Akio Yasuhara \\ Takeo Sakai, Satoshi Iwasaki, Hiroyuki Mukoudaka, Osamu Nozawa \\ and Michihiko Nozue
}

(Hamamatsu University School of Medicine)

Shinji Matsunaga and Tohru Kikawada

(Hamamatsu Ear, Nose and Throat Surgicenter)

\begin{abstract}
Various recently developed reconstructive procedures have made it possible to surgically treat advanced head and neck cancers that were previously considered inoperable. From 1979 through March, 1992, we extensively removed cancers followed by reconstruction from 120 patients (153 cases), the results of which are presented herein. For reconstruction, we used the myocutaneous or cutaneous flaps in 111 , alimentary tract in 38 , and rib or iliac bone graft in four cases. In the first reconstruction, 16 of the 121 cases $(13.2 \%)$ were unsuccessful. Among them free flaps were utilized in nine cases. It is important to improve the surgical techniques, and also to prevent postoperative bleeding and infection.
\end{abstract}

Key words: reconstruction, free flap, myocutaneous flap

はじめに

従来，再建と言えば胃管による咽頭再建を指 していたものが，最近では種々の皮弁や消化管 による多岐にわたった再建を示すよらになって いる．以前ならば手術不可能となっていたもの が手術可能になり根治治療が可能となったり, 術後の管理がより安全になったりしている.今 回, 私たちは開院以来施行してきた手術につい て，再建の面から検討し，その現況について報 告する.
対 象

対象は1979年 1 月から1992年 3 月までの13年 3 カ月の間に, 当教室で再建手術を行った 120 例（153件）である.らち初回再建例は121件で あった. 再建材料 1 つにつき 1 件とした.

\section{結果}

1 ）年齢分布・性別頻度（表 1)

年㱓分布および性別頻度を表 1 に示した. 50 ～70歳代が多く全体の $82.5 \%$ を占めた. 最低年 路令は38歳の舌癌症例であり, 最高年歯は 82 歳の 
下咽頭癌症例であった．性別では，男性95例で 女性は25例であった。

2 ）原発部位（表 2)

全例とも原疾患は悪性腫瘍であり，その原発 部位をみると，下咽頭51例 (42.5\%)，口腔35 例 (29.2\%)，喉頭18例 (15.0\%) が多かった. 口腔35例の内訳は, 舌26例, 口腔底 5 例, 煩粘 膜 4 例であった。 また，喉頭癌と食道癌および 下咽頭癌と食道癌1) の同時期発症の二重癌症例 が 2 例あった. 中咽頭癌 6 例のうち 4 例は扁桃 腺，2 例は軟口蓋原発であった．甲状腺癌症例 は, 気管, 咽頭, 頸部食道への浸潤があったた め, 喉頭, 気管, 咽頭, 頸部食道の合併切除を 行い咽頭再建を施行したものである.

3 ) 再建件数の推移（表 3 )

1979年 1 月から1992年 3 月までの 13 年 3 力月 の間に行った再建件数は153件であった。（筋） 皮弁を最初に使用したのは1983年であり, 舌癌 症例に対する大胸筋皮弁に上る口腔底再建であ った。 それ以前の 4 例はすべて胃管による咽頭 再建であった. 1985年以降は10～20件前後の再 建件数があった.

4) 再建部位の推移（表 4)

再建部位の年ごとの推移を表 4 に示した．原 疾患の頻度によるが，咽頭再建が最も多く92件 (60.1\%) を占め，これはどの年次でも同様で あった. 次に多いのは, 口腔底再建の30件 (19.6 \%) であるが，1986年と1990年に多かった。

5 ) 再建材料の推移（表 5 ）

再建材料の年ごとの推移を表 5 に示した. 全 体では大胸筋皮弁が64件（41.8\%） と最も多く 1986年以降は使用した再建材料のなかでは一番 多かった．胃管は下咽頭癌手術の際に咽頭再建 として使用して拉り，1980年と1988年を除いて 毎年行われていた。広背筋皮弁は年間执よそ2 〜 3 件使用されていた. 腹直筋皮弁は，1985年 と1986年に使用件数が多かった．DP 皮弁は 1985年に 3 件と1989年に 1 件使用しただけであ った．遊離皮弁の件数だけをみると1986年が11 件（腹直筋皮弁 6 , 前腕皮弁 4 件, 広背筋皮弁
表 1 年齢分布と性別

\begin{tabular}{cc}
\hline \hline 年路分布 & \\
$\sim 39$ 歳 & 2 例 \\
$40 \sim 49$ & 16 \\
$50 \sim 59$ & 37 \\
$60 \sim 69$ & 31 \\
$70 \sim 79$ & 31 \\
$80 \sim$ & 3 \\
\hline 計 & 120 例 \\
性 別 & \\
男 & \\
女 & 95 例 \\
\hline
\end{tabular}

表 2 原発部位

\begin{tabular}{lc}
\hline \hline 口腔 & 35 例 \\
中咽頭 & 6 \\
下咽頭 & 51 \\
上䅡 & 2 \\
䐅頭 & 18 \\
耳下腺 & 3 \\
聴器 & 2 \\
甲状腺 & 1 \\
喉頭 +食道 & 1 \\
下咽頭+食道 & 1 \\
\hline \multicolumn{1}{c}{ 計 } & 120 例
\end{tabular}

表 3 再建件数の推移

\begin{tabular}{lc}
\hline \hline 1979 年 & 1 件 \\
1980 & 1 \\
1981 & 0 \\
1982 & 2 \\
1983 & 14 \\
1984 & 3 \\
1985 & 16 \\
1986 & 22 \\
1987 & 18 \\
1988 & 10 \\
1989 & 18 \\
1990 & 23 \\
1991 & 20 \\
1992 年 3 月 & 5 \\
\hline 計 & 153 件
\end{tabular}


1 件）で最も多く，ついで1985年 6 件（腹直筋 皮弁 4 件, 前腕皮弁 1 件, 空腸 1 件)，1990年 5 件（空腸 2 件, 腹直筋皮弁 1 件, 前腕皮弁 1 件，広背筋皮弁 1 件）となっていた。

6 ) 再建部位と再建材料（表 6 ）

再建部位をみると, 咽頭の92件が圧倒的に多 く60.1\%を占めた. 以下, 口腔底30件 (19.6\%), 頸部皮膚12件（7.9\%)，顔面皮膚 7 件（4.6\%） と続き, 口腔, 口腔底咽頭および下顎口腔底が それぞれ 4 件 (2.6\%) であった。他方, 使用 した再建材料をみると大胸筋皮弁64件（41.8 $\%)$ ，胃管32件（20.9\%）が多く，以下，広背 筋皮弁17件 (11.1\%)，腹直筋皮弁13件 (8.5\%)， 前腕皮弁11件（7.2\%）と続き，下頡骨の再建
は, 腸骨 3 件, 胁骨 1 件であった. 腸骨は血管 柄付き腸骨として, 頸部で血管吻合を行い移植 した，有茎か遊離かをみると，大胸笳皮弁， DP 皮弁, 胸鎖乳突筋皮弁扎よび胃管, 結腸は 全件有茎であり，広背筋皮弁の17件中15件は有 茎であった. 他方, 前腕皮弁, 腹直筋皮弁, 腸 骨および空腸の全件と広背筋皮弁の 17 例中 2 例 が遊離であった。

再建部位と再建材料との関係をみると, 大胸 筋皮弁拉よび胃管による咽頭再建が32例ずつと もっとも多く, 以下大胸筋皮弁による口腔底再 建17例, 広背筋皮弁による咽頭再建12例と続い ていた。

表 4 再建部位の推移

(件)

\begin{tabular}{|c|c|c|c|c|c|c|c|c|c|c|c|c|c|c|c|}
\hline & $\begin{array}{l}1979 \\
\text { (年) }\end{array}$ & 1980 & 1981 & 1982 & 1983 & 1984 & 1985 & 1986 & 1987 & 1988 & 1989 & 1990 & 1991 & 1992.3 & 計 \\
\hline 口腔 & & & & & & & & & & 1 & & 1 & 2 & & 4 \\
\hline 口腔底 & & & & & 3 & 1 & 1 & 7 & 2 & 4 & 2 & 6 & 3 & 1 & 30 \\
\hline 口腔底咽頭 & & & & & & & 1 & & & & 3 & & & & 4 \\
\hline 咽頭 & 1 & 1 & 0 & 2 & 9 & & 11 & 11 & 15 & 4 & 11 & 11 & 10 & 4 & 92 \\
\hline 頸部皮膚 & & & & & & & 2 & 2 & & & 1 & 3 & 4 & & 12 \\
\hline 顔面皮膚 & & & & & & & 1 & 2 & 1 & 1 & & 1 & 1 & & 7 \\
\hline 下買口腔底 & & & & & 2 & & & & & & 1 & 1 & & & 4 \\
\hline 計 & 1 & 1 & 0 & 2 & 14 & 3 & 16 & 22 & 18 & 10 & 18 & 23 & 20 & 5 & 153 \\
\hline
\end{tabular}

表 5 再建材料の推移

(件)

\begin{tabular}{|c|c|c|c|c|c|c|c|c|c|c|c|c|c|c|c|}
\hline & $\begin{array}{c}1979 \\
\text { (年) }\end{array}$ & 1980 & 1981 & 1982 & 1983 & 1984 & 1985 & 1986 & 1987 & 1988 & 1989 & 1990 & 1991 & 1992.3 & 計 \\
\hline 大胸筋皮弁 & & & & & 4 & 1 & 3 & 9 & 9 & 7 & 10 & 9 & 10 & 2 & 64 \\
\hline 広背筋皮弁 & & & & & 1 & & & 3 & 3 & 2 & 3 & 3 & 2 & & 17 \\
\hline DP 皮弁 & & & & & & & 3 & & & & 1 & & & & 4 \\
\hline 胸鎖乳突筋皮弁 & & & & & & & & & & 1 & & 1 & & & 2 \\
\hline 前腕皮弁 & & & & & & & 1 & 4 & 1 & & & 1 & 2 & 2 & 11 \\
\hline 腹直筋皮弁 & & & & & & & 4 & 6 & & & & 1 & 2 & & 13 \\
\hline 胃管 & 1 & 1 & 0 & 2 & 7 & 1 & 4 & & 4 & & 2 & 5 & 4 & 1 & 32 \\
\hline 空腸 & & & & & & & 1 & & & & 1 & 2 & & & 4 \\
\hline 結腸 & & & & & & 1 & & & 1 & & & & & & 2 \\
\hline 腸骨 & & & & & 2 & & & & & & 1 & & & & 3 \\
\hline 肋骨付大胸筋皮弁 & & & & & & & & & & & & 1 & & & 1 \\
\hline 計 & 1 & 1 & 0 & 2 & 14 & 3 & 16 & 22 & 18 & 10 & 18 & 23 & 20 & 5 & 153 \\
\hline
\end{tabular}


7 ) 再建部位と再建材料（初回再建例） （表 7 ）

初回再建に限って再建部位と再建材料との関 係揖よび再建の失敗例を表 7 に示した，症例は 120 例で再建材料は121件であった．1例に揖い て下咽頭癌十食道癌の二重癌で胃管と空腸とを 同時使用した1)。再建部位については咽頭76件, 口腔底24件，頸部皮膚 5 件となっていた。また， 再建材料についてみると大胸筋皮弁47件，広背 筋皮弁11件，腹直筋皮弁11件となっていた。
8 ）再建失敗例の検討（表 8 ）

初回再建例121件（120例）のらち再建失敗と 判断したものは，16件（13.2\%）であった（筋） 皮弁の全壊死が11件, marginal necrosis が 3 件，胃管の縫合部壊死が 2 件であった，皮弁で みると, 遊離皮弁 9 件（腹直筋皮弁 3 件, 前腕 皮弁 2 件, 広背筋皮弁 2 件, 血管柄付腸骨 2 件) であり，有茎皮弁 5 件（大胸筋皮弁 2 件, DP 皮弁 2 件，広背筋皮弁 1 件）であった。

表 6 再建部位と再建材料 (件)

\begin{tabular}{|c|c|c|c|c|c|c|c|c|}
\hline & 口腔 & 口腔底 & 口腔底咽頭 & 咽頭 & 頸部皮膚 & 顔面皮膚 & 下㴿口腔底 & 計 \\
\hline 大胸筋皮弁 & 1 & 17 & 3 & 32 & 9 & 2 & & 64 \\
\hline 広背筋皮弁 & & 2 & & 12 & 2 & 1 & & 17 \\
\hline DP 皮弁 & & & & 3 & 1 & & & 4 \\
\hline 胸鎖乳突筋皮弁 & & 1 & & & & 1 & & 2 \\
\hline 前腕皮弁 & 3 & 5 & & 3 & & & & 11 \\
\hline 腹直筋皮弁 & & 5 & 1 & 4 & & 3 & & 13 \\
\hline 胃管 & & & & 32 & & & & 32 \\
\hline 空腸 & & & & 4 & & & & 4 \\
\hline 結腸 & & & & 2 & & & & 2 \\
\hline 腸骨 & & & & & & & 3 & 3 \\
\hline 肋骨付大胸筋皮弁 & & & & & & & 1 & 1 \\
\hline 計 & 4 & 30 & 4 & 92 & 12 & 7 & 4 & 153 \\
\hline
\end{tabular}

表 7 再建部位と再建材料（初回再建例） (件)

\begin{tabular}{|c|c|c|c|c|c|c|c|c|}
\hline & 口腔 & 口腔底 & 口腔底咽頭 & 咽頭 & 頸部皮膚 & 顔面皮瑭 & 下顎口腔底 & 計 \\
\hline $\begin{array}{l}\text { 大胸筋皮弁 } \\
\text { 広背筋皮弁 } \\
\text { DP 皮弁 } \\
\text { 胸鎖乳突筋皮弁 } \\
\text { 前腕皮弁 } \\
\text { 腹直筋皮弁 } \\
\text { 胃管 } \\
\text { 空腸 } \\
\text { 結腸 } \\
\text { 腸骨 }\end{array}$ & $3(1)$ & $\begin{array}{l}13 \\
1 \\
1 \\
5 \\
4(1)\end{array}$ & $1(1)$ & $\begin{aligned} 26 & (1) \\
7 & (2) \\
2 & (2) \\
& \\
1 & (1) \\
4 & (1) \\
30 & (2) \\
4 & \\
2 & \end{aligned}$ & $\begin{array}{l}4(1) \\
1\end{array}$ & $\begin{array}{ll} & \\
2 & (1) \\
1 & \\
2 & \end{array}$ & $3(2)$ & $\begin{aligned} 47 & (2) \\
11 & (3) \\
2 & (2) \\
2 & \\
9 & (2) \\
11 & (3) \\
30 & (2) \\
4 & \\
2 & \\
3 & (2)\end{aligned}$ \\
\hline 計 & $4(1)$ & $24(1)$ & $3(1)$ & $76(9)$ & $5(1)$ & $6(1)$ & $3(2)$ & $121(16)$ \\
\hline
\end{tabular}

（ ）内は失敗件数 
表 8 再建手術の失敗例のまとめ

\begin{tabular}{|c|c|c|c|c|c|c|}
\hline 症例 & 年齢・性 & 原発部 & 再建部位 & 再建材料 & 原 因 & 再手術 \\
\hline 1. & 59・男 & 下咽頭 & 咽頭 & LD & 出血 & $\mathrm{PMMC}+$ 植皮 \\
\hline 2. & 68・男 & 中咽頭 & 咽頭 & 遊離 LD & 縫合不全 & PMMC \\
\hline 3. & $72 \cdot 女$ & 口腔 & 口腔 & 前腕皮弁 & 縫合不全 & 自然治癒 \\
\hline 4. & 50・男 & 喉頭＋食道 & 咽頭 & 胃管 & 縫合不全・肝硬変 & 両 PMMC \\
\hline 5. & $50 \cdot$ 女 & 口腔 & 口腔底 & 腹直笳皮弁 & 感染 & PMMC \\
\hline 6. & 58 - 男 & 喉頭 & 咽頭 & 腹直笳皮弁 & 感染 & PMMC \\
\hline 7. & 71 ・男 & 聴器 & 顔面 & 遊離 LD & 縫合不全 & 腹直筋皮弁 \\
\hline 8. & $53 \cdot$ 女 & 中咽頭 & 咽頭 & 前腕皮弁 & 縫合不全 & PMMC \\
\hline 9. & 45・男 & 口腔 & 口腔底+咽頭 & 腹直筋皮弁 & 縫合不全 & $\mathrm{PMMC}+\mathrm{DP}$ \\
\hline 10. & 55 ·男 & 喉頭 & 咽頭 & DP 皮弁 & marginal & デブリドマン \\
\hline 11. & 74 - 男 & 喉頭 & 頸部 & PMMC & marginal & デブリドマン \\
\hline 12. & 57 ·男 & 喉頭 & 咽頭 & DP 皮弁 & marginal & デブリドマン \\
\hline 13. & 26 ·男 & 口腔 & 下顎 & 腸骨 & 感染 & プレート 固定PMMC \\
\hline 14. & $61 \cdot$ 男 & 口腔底 & 下顎 & 腸骨 & 静脈の折れ曲がり & プレート 固定PMMC \\
\hline 15. & 53 ·男 & 喉頭 & 咽頭 & PMMC & 感染 & LD \\
\hline 16. & 63・男 & 下咽頭 & 咽頭 & 胃管 & 縫合不全 & 死亡 \\
\hline
\end{tabular}

\section{考察}

再建手術の進歩により, 頭頸部癌の手術治療 の適応が拡大されている。 また，手術方法もよ り安全なものへと進歩している。それにつれて 対象患者も多岐にわたるようになっている.今 回私たちは1979年 1 月から1992年 3 月までの間 に再建手術を施行した120例（153件）について 検討した．年齡分布では40歳代16例，30歳代 2 例之, 癌患者が高齢者に多いにもかかわらず, 多くなっていた。これは，若いゆえに手術不可 能例にしないこと，術後の後遺症にたいしてリ ハビリテーションが期待できること，さらに合 併症が少ないこと，などによるものと思われる． また，男性に多いことは頭頸部癌患者自体が男 性に多いことによると思われる。

癌の原発部位をみると下咽頭, 舌が多く, こ れらは解剖学的にみても必ず再建が必要の部位 であることによる．他方，喉頭の場合喉頭蓋や 披裂部に生じると咽頭再建が必要となる．上顎 癌では, 拡大上顎全摘術後に顔面の再建を行う 場合があり，当科では腹直筋皮弁による再建を 行っている. 頭蓋底手術の一般化に伴い, 今後
増していくと思われる。また，喉頭癌十食道癌 の症例は咽喉食摘出後に胃管により咽頭再建を 行った。下咽頭癌十食道癌の症例では咽喉食摘 出後に胃管を挙上し，そこに遊離空腸をつない だ1). 今後, 高齢者患者が増加するにつれて二 重癌の治療の機会も増えると思われる．この方 法も一法と考兄られる。

再建部位の推移をみると, 咽頭や口腔底再建 が常に多いことがわかる．下咽頭癌と舌癌症例 が多いためである．再建部位は原発部によって 決定されるものであり，年毎の特殊性はないと 思われる。

再建材料の推移をみると，これは時代ごとの 遛勢があったり，あるいは術者の意見も大きく 関与している. 基本的に再建材料の違いによっ て生存率が左右されるものではなく, 術後の機 能の問題と術者の技量も含めた安全性の問題と から決められるものである，私たちは，簡便性 と安全性の点から大胸筋皮弁2) 4) を主体にし， 癌の進展範囲, 性別, 患者の体力などを考虑し て，多少変更している. 再建件数のらち遊離手 術を施行したものは，1985年と1986年に多く， 
特に1986年では22件中11件に行われている。 そ れ以降は年 $4 \sim 5$ 件となっている.

再建部位とその材料との関係をみると, 当科 では舌癌・下咽頭癌に対する大胸筋皮弁による 口腔底再建・咽頭再建が多い。しかし，胃管に よるものも32件ある.下咽頭癌は上方へ浸潤し てゆく傾向があり, 口腔側を十分に安全域をと って切除する必要がある. 胃管は口腔側への挙 上制限があるので, 輪状後部型で上方への進展 のない場合に限って最近では使用している。そ の他の場合は，（筋）皮弁や遊離空腸を使って いる. しかし，（筋）皮弁例では術後の狭窄の 問題もあり, 症例を考えて再建材料を選択すべ きである. 口腔底再建では, 舌亚全摘の症例で は大胸筋皮弁を, 舌全摘症例では腹直筋皮弁を 使用している，筋皮弁では術後に筋肉の萎縮が 生じるが，腹直筋皮弁では脂肪組織が多いため volume の減少が少なく, 再建部が陥凹しにく い利点がある。頸部皮膚の再建は, 再手術例に 多く，一番慣れた安全な大胸筋皮弁を使用して いる，遊離皮弁は，術後で血管に乏しく不適で ある. 胸鎖乳突筋皮弁は, 郭清範囲内にあるた め頭頸部領域の再建にはあまり使われていない， 私たちは 2 例に使用したが， 1 例は高齢者の聴 器癌症例で原発部が姑息的な切除になっており, 頸部リンパ節も触知されなかったため, 側頭部 の充媜を第一に考え胸鎖乳突筋皮弁を使った. 他の 1 例は, 肺癌の手術既往があり大胸筋皮弁 や広背筋皮弁や DP 皮弁などが採取できなかっ たこと，さらに，肺機能低下のため手術時間の 短縮の必要があり胸鎖乳突筋皮弁を使った. 頭 頸部癌のリンパ節転移は上深頸リンパ節に多い ことを考えると，やはりこの皮弁は緊急避難的 なものであると思われる.

初回再建例に限ってみると, やはり大胸筋㧧 よび広背筋皮弁が多いが，表 6 に比べてそれぞ れ17怙よび 6 件減少している。 これらは，再手 術時に使用されたものである. 失敗例について みると，咽頭再建例では76件中 9 件 (11.8\%), 口腔底では24件中 1 件 (4.2\%) であった。皮
弁でみると，大胸筋皮弁は47件中 2 件 (4.3\%)， 広背筋皮弁は11件中 3 件 $(27.3 \%)$, 前腕皮弁 は 9 件中 2 件 (22. $2 \%)$, 腹直筋皮弁は 11 件中 3 件（27.3\%）であった．広背筋皮弁の失敗例 3 件中 2 件は遊離で使用したものである. 全失 敗例16件中胃管を除いた14件についてみると， 有茎皮弁は60件中 5 件 (8.3\%)，遊離皮弁（腸 骨, 空腸も含む) は29件中 9 件 (31.0\%) であ った。この差は，血管吻合を必要とするか否か によると思われる。 また，遊離空腸5)の 4 件は 成功しており, donor site の血管の状態も関与 していると考兄られる。しかし，特に遊離皮弁 成績は他の報告677) に比べて憲く今後の改善が 望まれる。

失敗の原因は，手技上の問題と出血・感染に よる血管の圧迫の問題とがある. 手技上の問題 では，(1)採取部位が不適切な場合，(2)縫合不全， (3)静脈の折れ曲がり,などがある. 本例では, 表 8 の如く, DP 皮弁 2 件, 大胸筋皮弁 1 件の 3 件に打いて辺縁懐死を起こしており, 採取部 位に問題があったと思われる.すなわち, 咽頭 の口腔側へ高く移動させる際に無理をしたと考 えられる. しかし, 辺縁懐死の場合デブリドマ ンにより自然に上皮化してくるものである. 縫 合不全は静脈に生じやすく，これは技術の向上 が必要となる. 次に, 出血により血腫ができ血 管（主に静脈）を圧迫して，皮弁壊死が生じる こともあり，特に皮弁からの出血に注意し，血 腫の形成がみられた時は, 早急に除去するべき である，と思われる，さらに，死腔形成により 感染が生じ，血管を破壊あるいは閉塞すること もある. 死腔をつくらないことが大切であり， 筋肉弁で充填したり，持続吸引ドレーンを挿入 して対処する. 表 8 の如く, 一度皮弁が壊死す ると, 再手術時に頸部皮膚を含めた再建が必要 となる場合が多い，手術侵襲も大きくなり，二 重手間となるので十分注意することが大切であ る。

$$
\text { まとめ }
$$

1 ） 1979年 1 月から1992年 3 月までの間に施 
行された再建手術について報告した.

2 ) 全再建数は120例153件であり，再建部位 では咽頭，口腔底が多かった。

3 ）再建材料は大胸筋皮弁・広背筋皮弁が多 いが，腹直筋皮弁，前腕皮弁或いは胃管，空腸 など多岐にわたっていた。

4 ) 初回再建数 121 件のうち, 失敗件数は 16 件（13.2\%）であり，遊離皮弁が 9 件，有茎皮 弁が 5 件，胃管が 2 件であった。

5 ）手技の向上と, 術後の出血および感染を 防ぐことが大切である，と思われた。

\section{参考文献}

1）木村泰三, 吉田雅行, 桜町俊二, 他: 胃管に遊 離空腸の間置を加えた後縦隔路下咽頭食道再建 術. 手術 $44: 1689 \sim 1691,1990$.

2) Ossoff RH, Wurster CF, Berktold RE, et al : Complications after pectoralis major myocutaneous flap reconstruction of head and neck defects. Arch Otolaryngol Head Neck Surg $109: 812 \sim 814,1983$.

3) Baek S, Lawson W and Biller HF : An analysis of 133 pectoralis major myocutaneous flaps. Plast Reconstr Surg 69 : 460 467, 1982.

4) Schuller DE : Pectoralis myocutaneous flap in head and neck cancer reconstruction. Arch Otolaryngol Head Neck Surg 109 : 185 189, 1983.

5) Wang TD, Sun $Y E$ and Chen $Y$ : Free jejunal grafts for reconstruction of pharynx and cervical esophagus. Ann Otol Rhinol Laryngol $95: 348 \sim 351,1986$.

6) Soutar DS and McGregor IA : The radial forearm flap in intraoral reconstruction; the experience of 60 consecutive cases. Plast Reconstr Surg $78: 1 \sim 8,1986$.

7) Frampton MC, Breach NM, Archer DJ, et al : The use of free tissue transfer in reconstruction following head and neck tumour resection. J Laryngol Otol $100: 97 \sim 103,1986$.

$$
\left(\begin{array}{l}
\text { 別刷請求先 : 峯田周幸 } \\
\mathbf{T} 431-31 \text { 浜松市半田町 } 3600 \\
\text { 浜松医科大学耳鼻咽喉科学教室 }
\end{array}\right)
$$

